\title{
Ecophysiological responses of Mediterranean pines to simulated sea aerosol polluted with an anionic surfactant: prospects for biomonitoring
}

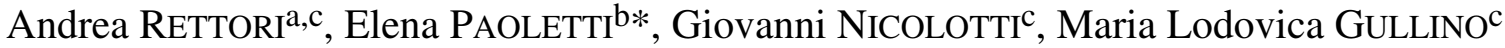 \\ ${ }^{a}$ DI.VA.P.R.A. - Plant Pathology, University of Torino, via Leonardo da Vinci 44, 10095 Grugliasco, Torino, Italy

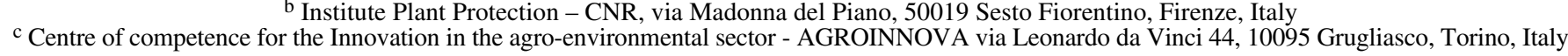

(Received 25 March 2004; accepted 25 October 2004)

\begin{abstract}
Sea aerosol may contain surfactants as pollutants. We examined ecophysiological mechanisms involved in the sensitivity of three Mediterranean pines to five spray treatments with sea water including an anionic surfactant, 5 to $500 \mathrm{mg} / \mathrm{L}$ dioctyl sodium sulphosuccinate. Despite the reduction of surfactant in sea aerosol over the past 20 years, Mediterranean pinewoods are still at risk for surfactant pollution, since concentrations in the field reach the visible injury threshold here recorded, i.e. $2 \mathrm{mg} / \mathrm{L}$ surfactant deposited on needles. The chloride toxicity threshold was $2 \mathrm{mg} / \mathrm{g}$ needle $\mathrm{dw}$; values exceeded the threshold only when sea water was polluted by more than $30 \mathrm{mg} / \mathrm{L}$ surfactant. The surfactant altered epistomatal waxy microtubules and thus needle water potential. The phytotoxic effect increased with time, even in the absence of further exposures ("delayed-action" effect). Needle chloride content appeared better suited for biomonitoring surveys than structural damage to stomata, quantity of epicuticular waxes, drop contact angle, or midday water potential. All three species were sensitive to injury, according to the order: $P$. pinea $>$ P. halepensis $>$ P. pinaster.
\end{abstract}

Aleppo pine / coastal forests / maritime pine / polluted sea-spray / stone pine

Résumé - Réponses écophysiologiques de quelques pins méditerranéens à un aérosol marin pollué artificiellement avec un surfactant anionique : perspectives pour un biocontrôle. Les embruns marins peuvent contenir des polluants. Dans le présent travail ont été étudiés et comparés les mécanismes écophysiologiques liés à la sensibilité de trois pins méditerranéens traités avec de l'eau de mer polluée avec cinq concentrations (de 5 à $500 \mathrm{mg} / \mathrm{L}$ ) de dioctyl sulfosuccinate de sodium. Malgré la réduction des surfactants dans l'eau de mer pendant les 20 dernières années, les pins méditerranéens ont encore des risques de dépérissement à caue des concentrations qui atteignent le seuil de dégât visible sur les aiguilles : $2 \mathrm{mg} / \mathrm{L}$ de surfactant déposé sur les aiguilles. Le seuil de toxicité du chlore était de $2 \mathrm{mg} / \mathrm{g}$ de poids sec des aiguilles ; les valeurs mesurées ont dépassé le seuil de toxicité lorsque l'eau de mer avait une concentration supérieure à $30 \mathrm{mg} / \mathrm{L}$ de surfactants. Le polluant a endommagé les tubes cireux épistomatiques et, par voie de conséquence, a eu un effet sur le potentiel hydrique des aiguilles. L'effet toxique a augmenté avec le temps, même en l'absence d'expositions ultérieures des aiguilles au polluant (effet «action prolongée »). Dans la perspective d'un suivi par un biocontrôle parmi les paramètres étudiés, le contenu en chlore des aiguilles semble être mieux indiqué que les dégâts stomatiques, la quantité des cires épicuticulaires, l'angle de contact de la goutte ou le potentiel hydrique. Les trois espèces se sont montrées sensibles aux différentes concentrations de surfactant, selon l'ordre suivant : $P$. pinea $>$ P. halepensis $>$ P. pinaster.

aérosol marin pollué / forêt littorale / pin dAlep / pin maritime / pin parasol

\section{INTRODUCTION}

In Europe annual consumption of surfactants contained in detergents for household and industrial use exceeds 1.5 Mton [31]. Since the 1970s, surfactants have been found in the sea water of several countries (Australia, France, Italy, Spain) and the role they play in the deterioration of coastal flora has been examined. In Israel [53], Turkey [51] and Ukraine [36], surfactants have been measured in sea water and rivers, but no studies have been carried out on coastal vegetation. In the United States (Virginia Beach) injury to coastal flora attributed to salt-water spray has been reported, but the involvement of surfactants has not been ascertained [2].

All plant species are sensitive to surfactant-polluted sea aerosol, as is shown by the vast literature: Araucaria heterophylla in Australia [15, 33, 49], Pinus halepensis in the south of France [4-6, 17] and in the south of Italy [41], P. pinea, $P$. halepensis $[9,19-21,29]$ and several species of broadleaves and conifers along the Tyrrhenian coast in Italy [38] and the Barcelona coast in Spain [3, 32], Acacia cyanophylla and Eucalyptus gomphacephala in the Cap Bon peninsula in Tunisia [16].

\footnotetext{
* Corresponding author: e.paoletti@ipp.cnr.it
} 
The damage to coastal flora occurs primarily in coastlands with highly anthropized inland regions, in coastal areas adjacent to river mouths or sewage outlets, and anywhere sea currents and winds concentrate urban and industrial effluents at the sea-surface. The phenomenon is due to the synergic effect of marine salt and surfactants, but also to the direct action of the surfactant itself which attacks cell membranes [25], increases cuticle permeability [46], and dissolves epicuticular and epistomatal waxes $[12,19,39,43,44,52]$, all phenomena that enhance the foliar absorption of salt and surfactant, and thus the phytotoxic effect [48].

The response of forest species to treatments with surfactants and sea water has been studied examining: chloride ion in foliar tissues [11, 23], water potential and gas exchange [8], damage to stomata and epicuticular waxes [12, 43, 44], foliar anatomy [10-12], pollen germination [34, 40]. Guidi et al. [22] compared chloride accumulation and visible injury in the three typically Mediterranean pines ( $P$. halepensis Mill., $P$. pinea L., and $P$. pinaster L.), two months after a single $60 \mathrm{~min}$ exposure to $240 \mathrm{mg} / \mathrm{L}$ of sodium alchyl sulphonate in synthetic sea water, suggesting the following sensitivity scale: $P$. pinea $>P$. halepensis $>P$. pinaster. Functional response to saline solutions containing surfactants was further investigated separately in $P$. halepensis [4, 6, 45], P. pinea [3, 10-12, 20, 23], and $P$. pinaster $[19,21]$ in field or controlled conditions.

Our aims were: (1) to study the ecophysiological mechanisms involved in the sensitivity of Mediterranean pines to surfactant-polluted sea sprays; (2) to compare species-specific sensitivity; (3) to determine the most useful parameters for biomonitoring surveys. The following parameters were considered: morphological (visible injury), chemical (needle content of chloride ions), physiological (midday water potential) and the leaf-atmosphere interface (stomatal damage, quantity of epicuticular waxes, needle wettability).

\section{MATERIALS AND METHODS}

\subsection{Plant material and treatments}

Experimental material consisted in 50 plants each of 5-year-old $P$. pinea, $P$. halepensis and $P$. pinaster, ranging in height from 0.8 to $1.40 \mathrm{~m}$, growing in $5 \mathrm{~L}$ pots. All plants were symptom-free and had differentiated secondary needles. Irrigation was regularly provided every week, to field capacity.

Sea water was collected from a depth of $2 \mathrm{~m}$, at a distance from the shore. To ensure the water contained no surfactant, it was examined using the Methylene Blue Active Substances (MBAS) method [30]. The water was stocked at $5{ }^{\circ} \mathrm{C}$ until it was used. Spraying was performed with an air compressor connected to a spray-gun; air pressure at outlet was $4 \mathrm{~atm}$. Spray flux was regulated so as to obtain drops measuring 70 to $150 \mu \mathrm{m}$ in diameter. Spraying was carried out in a PVC tunnel measuring $180 \mathrm{~W} \times 70 \mathrm{D} \times 190 \mathrm{H} \mathrm{cm}$, located inside a greenhouse, at ambient light (40\% lower than the irradiance outside the greenhouse), $20 \pm 2{ }^{\circ} \mathrm{C}$ temperature, $60 \%$ air relative humidity. As on the Tyrrhenian coastal regions of Italy the wind storms occur frequently in winter [42], a spraying per week was administered starting in December for a 5-week period. The solution sprayed was sea water mixed with a LAS (linear alchyl sulphonate), a category that includes the most common anionic surfactants present in commercial detergents [37]. The LAS used was dioctyl sodium sulphosuccinate (com- mercial name: AEROSOL $\left.{ }^{\circledR}-\mathrm{OT}\right)$ at the following concentrations: 0 (controls), 5, 10, 15, 30, 60, 120, 250, and $500 \mathrm{mg} / \mathrm{L}$. Hereinafter the treatments will be identified as PSW (polluted sea water) followed by the $\mathrm{mg} / \mathrm{L}$ of surfactant. Alongside the test with sea water (SW), performed in order to assess the effect of salt, there was a second control group treated with de-ionized water (DW) to verify the effect of water striking the cuticles. In each treatment 5 plants per species were sprayed to dripping point ( $50 \mathrm{~mL}$ solution). To avoid soil contamination, the pots were covered with a polyethylene film during spraying.

Observations were carried out on current year needles, three plants per species and per treatment, at the end of the sprayings and two months later. Some destructive measurements (water potential, needle wettability and amount of epicuticular waxes) were performed only at day 60 after the sprayings. Assessment of visible injury was carried out at the end of the treatments, and after 14, 30, and 60 days.

\subsection{Assessment of visible injury}

Visible injury assessment used the method proposed by Gellini et al. [20], that assesses the length of both the apical yellowing and of the necrotic patches, and classifies the injury according to the scale: $0=$ no injury; $1=<1 \mathrm{~mm}$ apical yellowing; $2=5-10 \mathrm{~mm}$ apical yellowing and necrosis; $3=<1 / 3$-needle-length apical yellowing and necrosis; $4=1 / 3 \div 2 / 3$-needle-length apical yellowing and necrosis; $5=$ dead needle. The attribution to a class was based on the most frequent injury found in 30 needles randomly selected from each of three plants per treatment.

\subsection{Chemical analyses}

The quantity of surfactant accumulated on the needles was measured at the end of treatments, in order to check the correlation between quantity sprayed and quantity deposited. Twenty grams of fresh needles from each plant were washed in a litre of de-ionized water and the washing solution was analysed using the MBAS method [30].

Chloride was chosen as the indicator of salt-induced toxicity since it generally accumulates in greater quantities in the leaves than sodium [48] and because sodium and chloride contribute equally to toxicity in $P$. pinea [23]. Ten grams of intact fresh needles per plant were washed 5 times in de-ionized water, for 5 min each time, in order to remove salt deposited on the surface. $\mathrm{Cl}^{-}$content in needle tissues was calculated using the volumetric method [1] and referred to needle dry weight (dw) obtained at $80{ }^{\circ} \mathrm{C}$ until a constant weight was reached.

\subsection{Stomatal damage}

Five needles per plant were picked with tweezers and air-dried. Apical and median portions from each needle, each portion measuring $5 \mathrm{~mm}$ in length, were fixed on stubs and sputtered with a $18 \mathrm{~nm}$ layer of gold (18 mA, 0.03 Torr, $60 \mathrm{~s}$, sputter coater E5000C PS3). Observations were carried out with a Philips 505 SEM (Eindhoven, Holland) at $15 \mathrm{kV}$. A hundred stomata per sample were classified according to Figure 1. A Stomatal Damage Index (SDI) was computed following Raddi et al. [44]. Identification of salt crystals was performed by means of an EDAX 9800 P.501B probe.

\subsection{Midday water potential}

Water potential was measured during the hottest hours (11 a.m.2 p.m.) using an SKPM 1400 pressure chamber (Skye Instruments, Powys, UK). Since the $P$. pinea and $P$. pinaster needles were large enough, measurements were performed directly on current year needles; measurements in $P$. halepensis were carried out on current year branchlets. Three measurements per each plant were performed. 

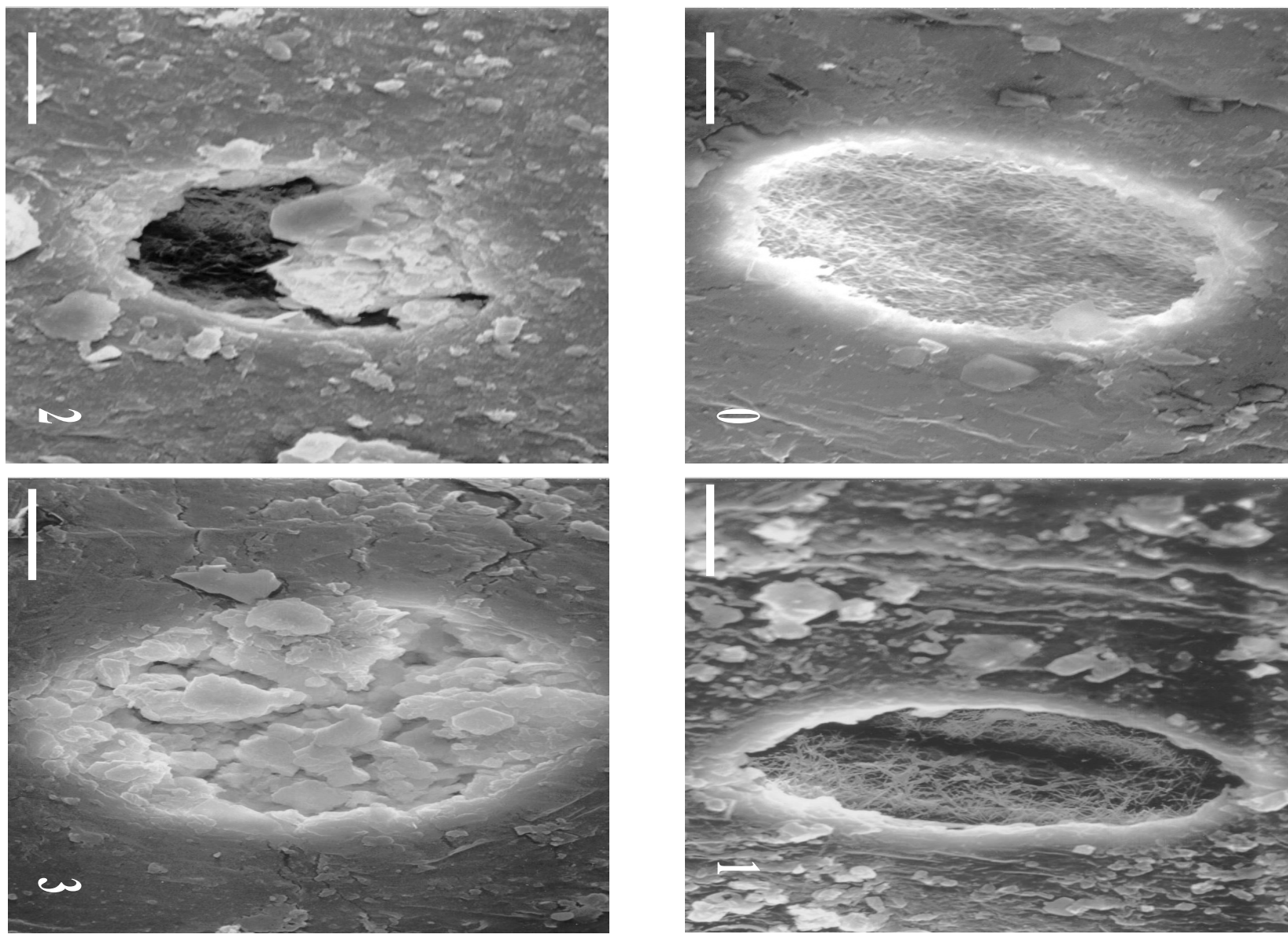

Figure 1. Stomatal damage classes: 0, no sign of stomatal alteration, no wax granules or crystals on the network of intact wax microtubules, each one separate from the others. 1, slight stomatal alteration, such as wax granules or crystals on the network of wax microtubules, still intact and separate, or with a few coalesced elements. 2, moderate stomatal alteration, wax granules and crystals obstruct up to $50 \%$ of the stomatal opening; about half of microtubules are coalesced. 3, severe stomatal alteration, wax granules and crystals obstruct the whole epistomatal cham-

\subsection{Quantity of epicuticular wax and needle wettability}

Five $\mathrm{g}$ fresh needles per plant were shaken for $10 \mathrm{~s}$ with $50 \mathrm{~mL}$ chloroform [14]. The solution was filtered through $0.2 \mu \mathrm{m}$ PTFE membranes, vacuum-reduced, transferred by washing to a pre-weighed aluminium container and allowed to evaporate to constant weight in a fume cupboard at room temperature. The residue was weighed by a balance with a $0.1-\mathrm{mg}$ readability. The amount of chloroform extractable wax was related to the total needle surface area, determined using Johnson's [27] technique for 2-needled pines.

Wettability of 10 fresh needles per plant was assessed as $1.5 \mu \mathrm{L}$ water-drop contact angle (DCA) using a bench microscope equipped with protractor graticule [13]. Measurements were replicated twice per each needle.

\subsection{Statistical analysis}

The statistical unit was the single plant. After testing that variables' distribution was parametric, data were collectively analysed using a two-factor multivariate analysis of variance (MANOVA) to test the effect of treatment and pine species at 60 days after the last spraying. The date of sampling was not considered as a factor, because several variables were recorded only at 60 days. Wilks' lambda was used to test the significance of MANOVA. Before MANOVA, all variables were tested for inter-correlation and those that were correlated $(p<0.05)$ were removed. Therefore, MANOVA included only needle chloride content and amount of epicuticular waxes. Two- or three-way analysis of variance (ANOVA) was used to assess which factors (date of sampling - when available -, treatment and species) significantly influenced each variable. Means were compared using Tukey's HSD test $(p<0.05)$. Different letters in Figures $2-8$ indicate significant differences among means. When more than three letters were present (e.g. abcdef), a short notation was used ( $a-f)$. Asterisk significance is reported in the caption of Table I. Linear regressions were applied to test the species-specific correlations between variables. All analyses were performed by Statistica 5.1 for Windows.

\section{RESULTS}

\subsection{Surfactant deposition on needles}

The quantity of surfactant sprayed on the three species and the amount deposited on the crowns showed a linear correlation $(r>0.99)$ according to the equations in Figure 2. The amount of surfactant deposited on the needles was about $6.5 \%$ of the amount sprayed. 
Table I. Significance levels in the correlation matrix between variables: $* x \leq 0.05,{ }^{* *} p \leq 0.01, * * * p \leq 0.001, \mathrm{~ns}: p>0.05$.

\begin{tabular}{|c|c|c|c|c|c|c|}
\hline & Visible injury & $\mathrm{Cl}^{-}$content & Water potential & Stomatal damage & Epicuticular waxes & Drop contact angle \\
\hline $\begin{array}{l}\text { Visible } \\
\text { injury }\end{array}$ & 1 & & & & & \\
\hline $\begin{array}{l}\mathrm{Cl}^{-} \\
\text {content }\end{array}$ & $\begin{array}{c}<0.001 \\
* * *\end{array}$ & 1 & & & & \\
\hline Water potential & $\begin{array}{c}<0.001 \\
* * *\end{array}$ & $\begin{array}{c}<0.001 \\
* * *\end{array}$ & 1 & & & \\
\hline Stomatal damage & $\begin{array}{c}<0.001 \\
* * *\end{array}$ & $\underset{* * *}{0.001}$ & $\begin{array}{c}<0.001 \\
* * *\end{array}$ & 1 & & \\
\hline Epicuticular waxes & $\begin{array}{c}0.019 \\
*\end{array}$ & $\begin{array}{c}0.086 \\
\mathrm{~ns}\end{array}$ & $\begin{array}{c}0.635 \\
\mathrm{~ns}\end{array}$ & $\begin{array}{c}0.969 \\
\mathrm{~ns}\end{array}$ & 1 & \\
\hline Drop contact angle & $\begin{array}{c}0.035 \\
*\end{array}$ & $\begin{array}{c}0.186 \\
\mathrm{~ns}\end{array}$ & $\begin{array}{c}<0.001 \\
* * *\end{array}$ & $\begin{array}{c}0.034 \\
*\end{array}$ & $\begin{array}{c}0.003 \\
* *\end{array}$ & 1 \\
\hline
\end{tabular}

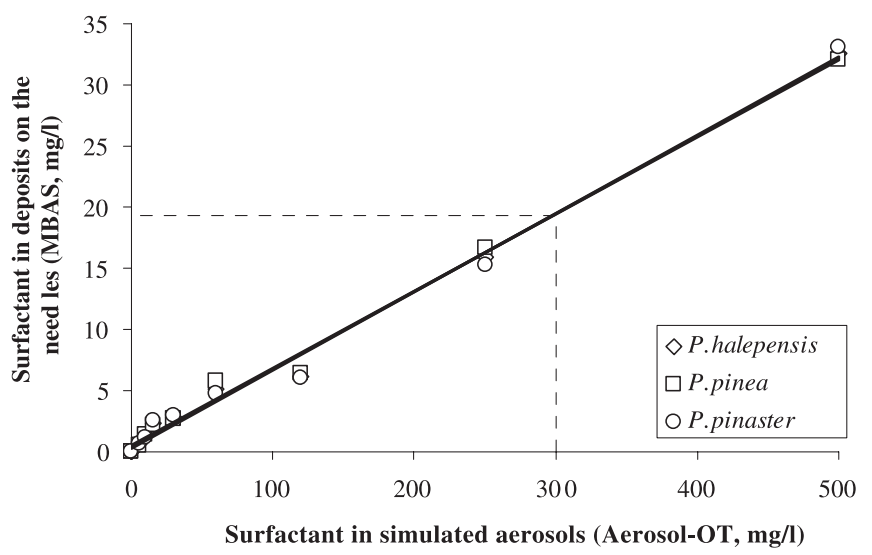

Figure 2. Relationship between the amount of surfactant (expressed as Methylene Blue Active Substances) deposited on the needles and the surfactant concentration in the spraying solutions. Regression lines (solid) for the three species overlap each other (Pinus halepensis, $\mathrm{y}=0.0649 \mathrm{x}, r=0.997 * * * ; P$. pinea $, \mathrm{y}=0.0646 \mathrm{x}, r=0.997 * * *$; $P$. pinaster, $\left.\mathrm{y}=0.0647 \mathrm{x}, r=0.998^{* * *}\right)$. Dashed lines show that spraying $300 \mathrm{mg} / \mathrm{L}$ surfactant by this experimental set-up determines an average deposition on the needles of $19.4 \mathrm{mg}$ MBAS per litre of washing water, i.e. the amount of surfactant deposited was about $6.5 \%$ of the amount sprayed, without species-specific differences.

\subsection{Visible injury}

Leaves sprayed with DW or SW showed no visible injury (Fig. 3). At the end of the sprayings, injury was present only in PSW30 and above, and consisted in yellowing measuring less than $1 \mathrm{~mm}$ (class 1 ). In later observations, the injury remained below class 4 in $P$. pinaster; in $P$. halepensis there were class 4 injuries with PSW250 and PSW500 at 60 days from sprayings; and in P. pinea with PSW120 and above at 60 days and with PSW250 and PSW500 at 30 days (Fig. 3).

\subsection{Needle chloride content}

At the end of the sprayings (Fig. 4), needle $\mathrm{Cl}^{-}$content in each species did not differ between the DW and SW treatment, and was lower than $2000 \mu \mathrm{g} / \mathrm{g} \mathrm{dw}$ from PSW5 to PSW30. Above PSW30 (PSW15 in $P$. pinea), $\mathrm{Cl}^{-}$content gradually increased, with $P$. pinea reaching the highest values. Two months after sprayings (Fig. 4), $\mathrm{Cl}^{-}$content in $P$. halepensis and $P$. pinaster needles was still lower than $2000 \mu \mathrm{g} / \mathrm{g}$ from PSW5 to PSW15 (PSW30 in P. pinaster), and did not differ as compared to DW and SW. $\mathrm{Cl}^{-}$content in $P$. pinea was higher in SW than in DW needles. The surfactant increased $\mathrm{Cl}^{-}$content in $P$. pinea needles already at PSW5, even if the content remained below $2000 \mu \mathrm{g} / \mathrm{g}$ until PSW15. From PSW30 to above, the increase became exponential. The three species showed significantly different values from one another starting from PSW30 (P. pinea $>P$. halepensis $>P$. pinaster $)$.

\subsection{Stomatal damage}

SEM observations showed intact stomata in DW needles. Needles treated with SW and PSW presented alterations to the epicuticular wax structures and to the network of microtubules in the epistomatal chambers, inside which accumulations of wax and salt crystals were observed (Fig. 1). A statistical comparison of the SDI values recorded in the apical and median portions of the needles did not reveal significant differences. As a result, the findings were organized in a single series per needle. By the end of the treatment (Fig. 5), each species' SDI was significantly higher than in controls from PSW30 upwards. SDI increased with increasing surfactant concentrations. $P$. pinaster proved to be the most damaged. Two months later (Fig. 5), SDI was higher in $P$. pinea and in $P$. halepensis at all concentrations (except DW and SW) compared to the end of the treatments, whereas in $P$. pinaster there was a decrease at PSW500. Until PSW30, $P$. pinaster was the species with the most severe stomatal damage. From PSW60 upwards, SDI increased so considerably in both $P$. pinea and $P$. halepensis that it equalled and eventually exceeded the SDI in $P$. pinaster. The highest value was recorded in $P$. pinea at PSW500.

\subsection{Midday water potential}

Needles from the DW and SW treatments showed no significant differences in their water potential (Fig. 6). As the concentrations of surfactant increased, the water potential 

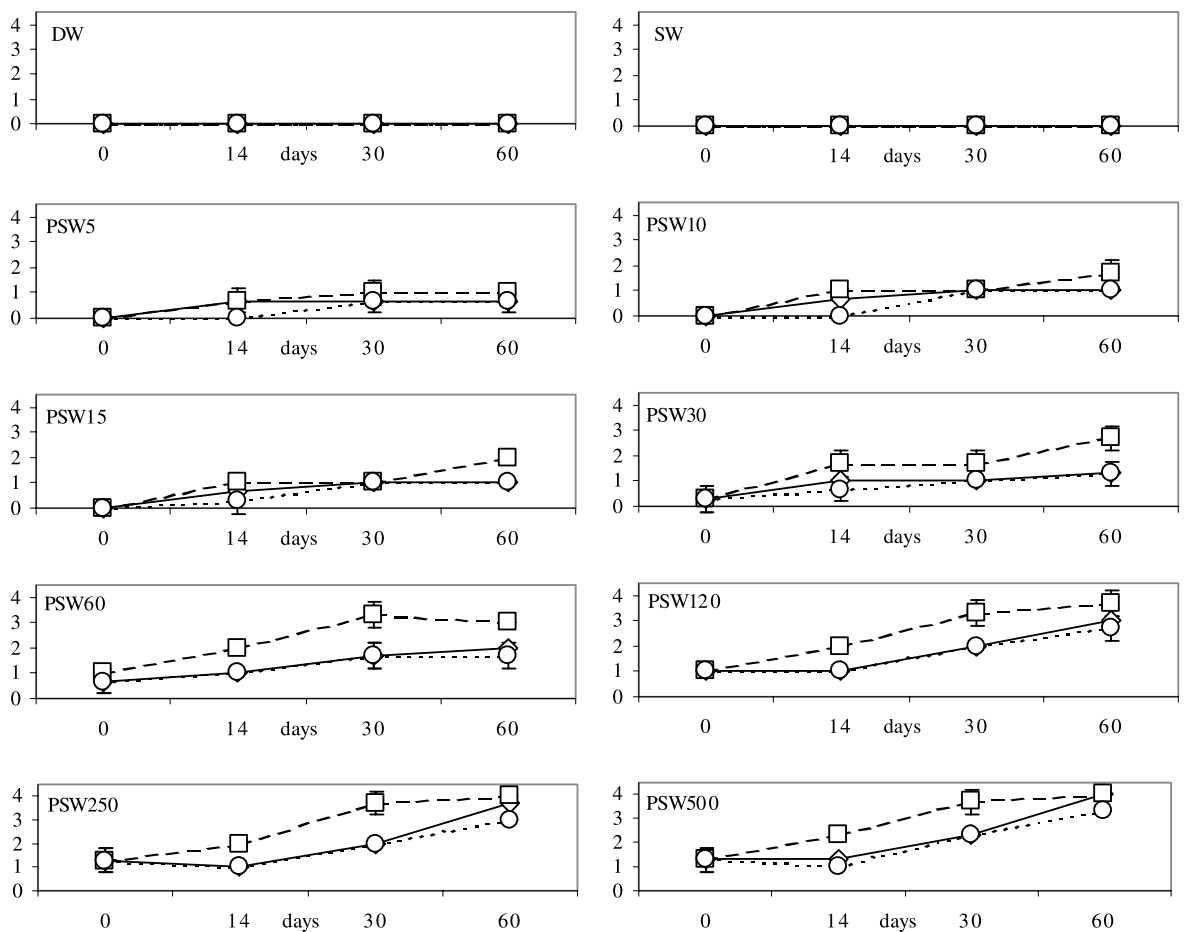

Figure 3. Score of visible injury ( 0 , no injury; $1,<1 \mathrm{~mm}$ yellowing; $2,5-10 \mathrm{~mm}$ yellowing and necrosis; 3 , $<1 / 3$-needle-length yellowing and necrosis; $4,1 / 3 \div 2 / 3$-needle-length yellowing and necrosis; 5 , dead needle) on current-year needles of Pinus halepensis $(\diamond-)$, P. pinea ( $\square--\rightarrow$, and $P$. pinaster (O - - ), at 0,14, 30 and 60 days after the sprayings (DW, deionized water; SW, sea water; PSW5-500, 5 to $500 \mathrm{mg} / \mathrm{L}$ surfactant in sea water). $n=3, \pm \mathrm{SD}$.
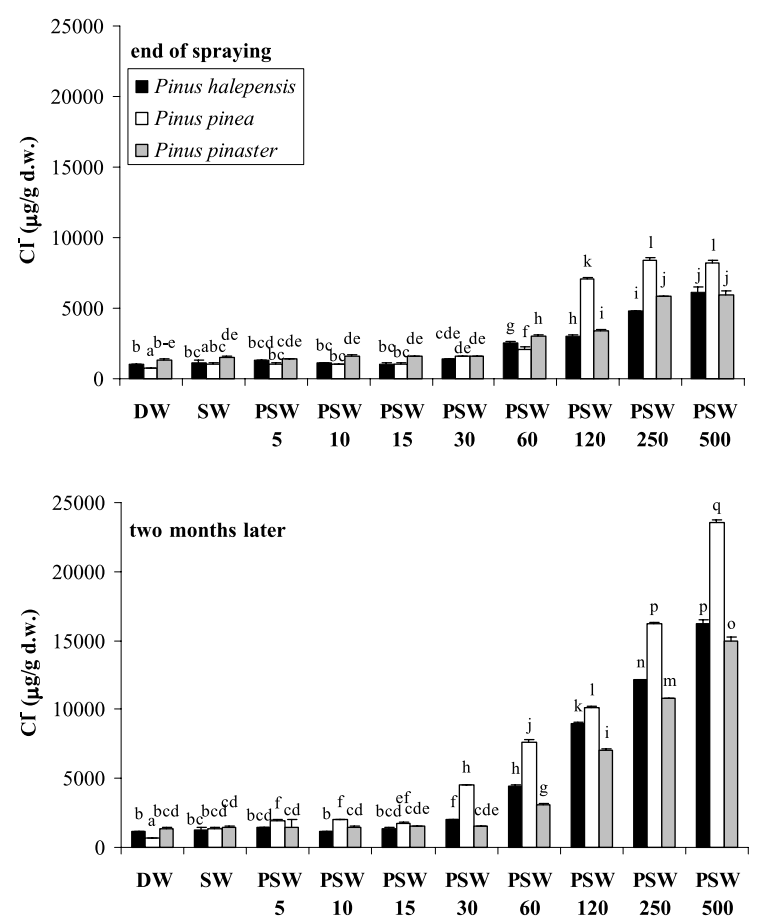

Figure 4. Chloride ion content $(+\mathrm{SD})$ in current-year needles at 0 and 60 days after the treatments (DW, deionized water; SW, sea water; PSW5-500, 5 to $500 \mathrm{mg} / \mathrm{L}$ surfactant in seawater). Different letters show significant differences (Tukey HSD test, $p<0.05, n=3$ ) among the bars in each graph.
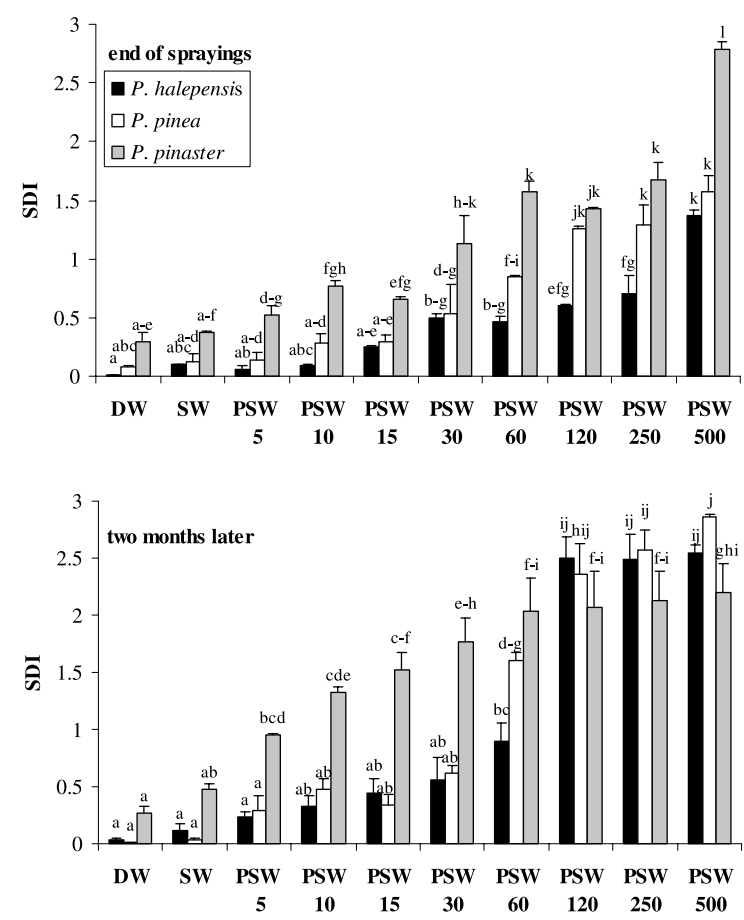

Figure 5. Stomatal Damage Index (+SD) in current-year needles at 0 and 60 days after the treatments (DW, deionized water; SW, sea water; PSW5-500, 5 to $500 \mathrm{mg} / \mathrm{L}$ surfactant in sea water). Different letters show significant differences (Tukey HSD test, $\mathrm{p}<0.05, n=3$ ) among the bars in each graph. 


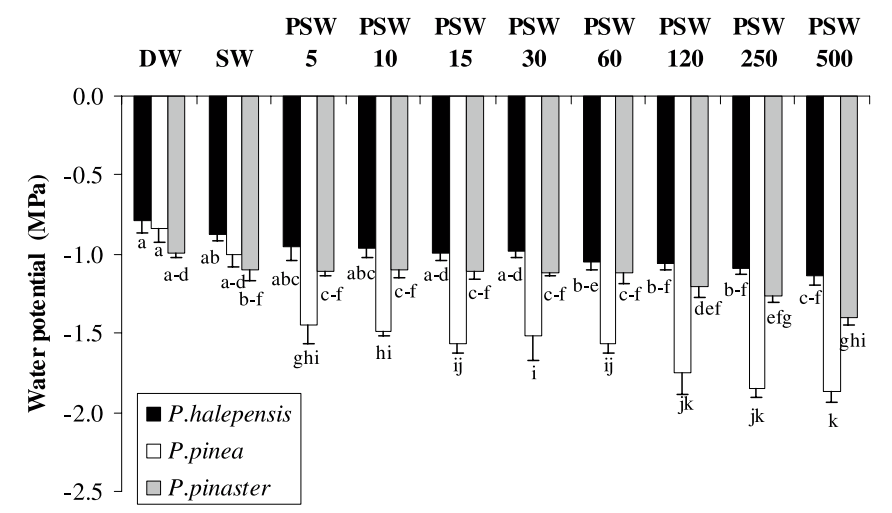

Figure 6. Midday water potential (-SD) in current-year needles at 60 days after the treatments (DW, deionized water; SW, sea water; PSW5-500, 5 to $500 \mathrm{mg} / \mathrm{L}$ surfactant in sea water). Different letters show significant differences (Tukey HSD test, $p<0.05, n=3$ ) among the bars in each graph.

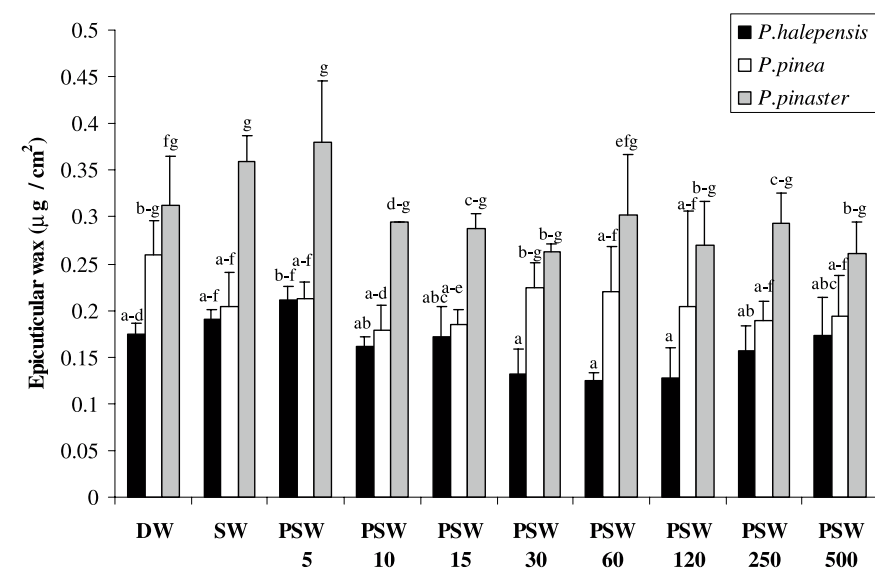

Figure 7. Amount of epicuticular waxes (+SD) in current-year needles at 60 days after the treatments (DW, deionized water; SW, sea water; PSW5-500, 5 to $500 \mathrm{mg} / \mathrm{L}$ surfactant in sea water). Different letters show significant differences (Tukey HSD test, $p<0.05, n=3$ ) between bars in each graph.

decreased. As compared to DW, the greatest decrease was measured in $P$. pinea (124\%) and the lowest in $P$. pinaster $(30 \%)$ that showed significant differences compared to SW only at PSW500.

\subsection{Quantity of epicuticular waxes and needle wettability}

The only significant variation in the amount of epicuticular waxes was a reduction at PSW30 to PSW120 in P. halepensis as compared to PSW5 (Fig. 7). The quantity of wax in P. pinaster needles was higher than that of the other species, regardless of treatments. None species responded to the treatments in terms of needle wettability (Fig. 8).
Table II. MANOVA results for the effects of treatment and pine species on the uncorrelated variables, i.e. needle $\mathrm{Cl}^{-}$content and amount of epicuticular waxes, at 60 days after the treatments.

\begin{tabular}{lcccc}
\hline Source & d.f. 1 & d.f. 2 & Wilks' lambda & Sign. lev. \\
\hline Treatment & 18 & 118 & 0.00107 & $<0.001$ \\
Species & 4 & 118 & 0.00102 & $<0.001$ \\
Treatment $\times$ Species & 36 & 118 & 0.00223 & $<0.001$ \\
\hline
\end{tabular}

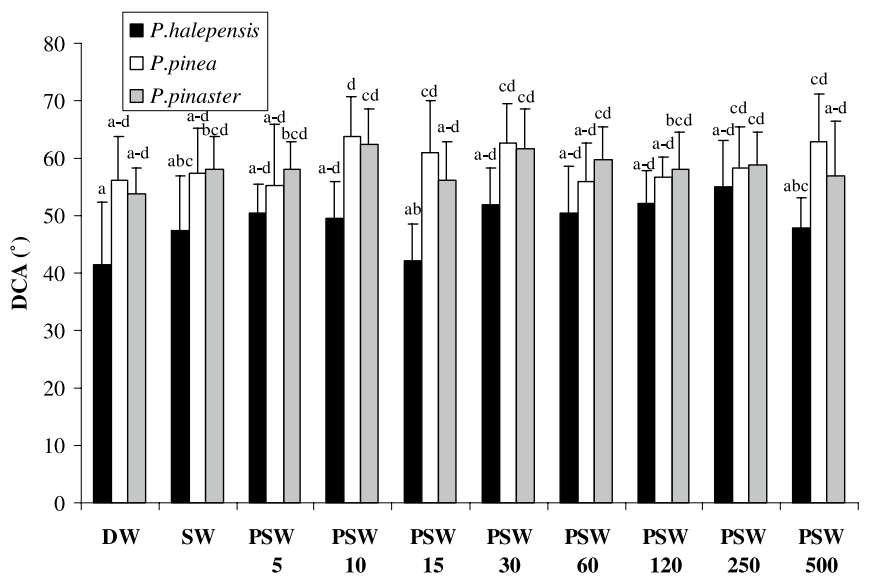

Figure 8. Drop Contact Angle (+SD) in current-year needles at 60 days after the treatments (DW, deionized water; SW, sea water; PSW5-500, 5 to $500 \mathrm{mg} / \mathrm{Ll}$ surfactant in sea water). Different letters show significant differences (Tukey HSD test, $p<0.05, n=3$ ) among the bars in each graph.

\subsection{Correlation between variables}

Most variables correlated to each others (Tab. I). Figure 9 shows the most interesting correlations species by species. Visible injury increased as $\mathrm{Cl}^{-}$content in the tissues increased, with minimal variations in the species-specific response. Above $5000 \mu \mathrm{g} / \mathrm{g} \mathrm{Cl}^{-}, P$. halepensis showed more severe visible injuries at a given $\mathrm{Cl}^{-}$content as compared to $P$. pinaster and - especially - to $P$. pinea (Fig. 9A). Visible injury increased as water potential decreased, and the species-specific sensitivity was still $P$. halepensis $>P$. pinaster $>P$. pinea, but with greater variations between the species (Fig. 9B). More severe visible injury went together with a higher stomatal damage; $P$. pinaster and $P$. pinea showed the highest SDIs at a given visible injury (Fig. 9C). The amount of epicuticular waxes - which in $P$. pinaster was on average two fold the other species - decreased as visible injury increased, although this response was not significant in $P$. pinea (Fig. 9D). Interestingly, the amount of epicuticular waxes did not correlate with $\mathrm{Cl}^{-}$ content, stomatal damage, and water potential (Tab. I).

MANOVA was applied only to the variables that did not correlate, i.e. $\mathrm{Cl}^{-}$content and amount of epicuticular waxes, and yielded significant effects for both factors (treatment and species) as well as for their interaction (Tab. II), suggesting species-specific sensitivity to the treatments. Two- or three-way ANOVA, applied for the individual variables, confirmed treatment 

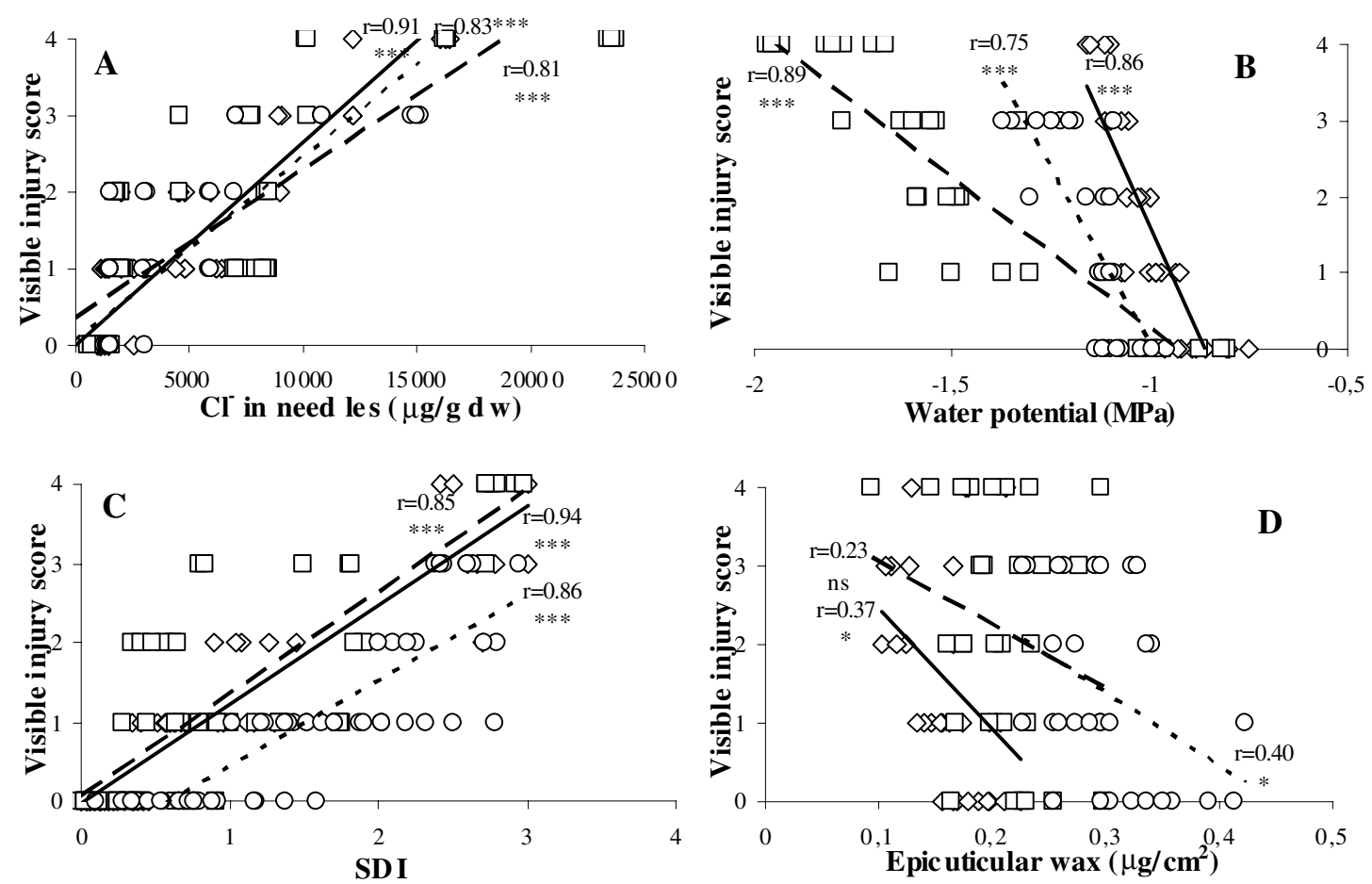

Figure 9. Linear regressions between variables in Pinus halepensis $\left(\nabla_{-}\right)$, P. pinea $\left(\square \longrightarrow\right.$, and $P$. pinaster $\left(\mathrm{O}_{-}---\right)^{-} n=60$ for needle visible injury, $\mathrm{Cl}^{-}$content in needles, and Stomatal Damage Index. $n=30$ for midday water potential and Drop Contact Angle.

Table III. Significance levels of two- and three-ways analyses of variance of the effects of treatments (deionized water; sea water; and 5 to $500 \mathrm{mg} / \mathrm{L}$ surfactant in sea water), pine species (P. halepensis, P. pinea, and P. pinaster), and date of sampling (end of sprayings and two months later).

\begin{tabular}{|c|c|c|c|c|c|c|}
\hline Source & Visible injury & $\mathrm{Cl}^{-}$content & Water potential & Stomatal damage & Epicuticular waxes & Drop contact angle \\
\hline \multirow{2}{*}{ Treatment } & $<0.001$ & $<0.001$ & $<0.001$ & $<0.001$ & 0.002 & 0.054 \\
\hline & $* * *$ & $* * *$ & $* * *$ & $* * *$ & $* * *$ & ns \\
\hline \multirow{2}{*}{ Species } & $<0.001$ & $<0.001$ & $<0.001$ & $<0.001$ & $<0.001$ & $<0.001$ \\
\hline & $* * *$ & $* * *$ & $* * *$ & $* * *$ & $* * *$ & $* * *$ \\
\hline Date & $\begin{array}{c}<0.001 \\
* * *\end{array}$ & $\begin{array}{c}<0.001 \\
* * *\end{array}$ & - & $<0.001$ & - & - \\
\hline \multirow{2}{*}{ Treatment $\times$ Species } & 0.201 & $<0.001$ & $<0.001$ & $<0.001$ & 0.176 & 0.557 \\
\hline & ns & $* * *$ & $* * *$ & $* * *$ & ns & ns \\
\hline Treatment $\times$ Date & $\begin{array}{c}<0.001 \\
* * *\end{array}$ & $<0.0001$ & - & $\begin{array}{c}<0.001 \\
* * *\end{array}$ & - & - \\
\hline Species $\times$ Date & $\begin{array}{c}<0.001 \\
* * *\end{array}$ & $\begin{array}{c}<0.001 \\
* * *\end{array}$ & - & $\begin{array}{c}<0.001 \\
* * *\end{array}$ & - & - \\
\hline $\begin{array}{l}\text { Treatment } \times \text { Species } \\
\times \text { Date }\end{array}$ & $\begin{array}{c}0.470 \\
\mathrm{~ns}\end{array}$ & $\begin{array}{c}<0.001 \\
* * *\end{array}$ & - & $\begin{array}{c}<0.001 \\
* * *\end{array}$ & - & - \\
\hline
\end{tabular}

and species effects, as did the sampling date, when this factor was available (Tab. III). DCA was the only variable to be not influenced by the treatments. The interaction treatment $\mathrm{x}$ species was not significant only for visible injury, epicuticular wax amount and drop contact angle.

\section{DISCUSSION}

Neither unpolluted sea water nor freshwater caused visible injury to any species. This confirms that marine aerosol becomes phytotoxic due to surfactants $[5,11,15,19-21]$. In all species 
the threshold for the onset of visible injury at the end of sprayings was $30 \mathrm{mg} / \mathrm{L}$, which in this study meant about $2 \mathrm{mg} / \mathrm{L}$ of MBAS deposited on the needles, as the deposition on needles was a constant percentage $(6.5 \%)$ of the sprayed concentration, regardless of the species. This suggests that the three pines have the same ability to intercept sea aerosols.

In the past, concentrations of MBAS measured in the field could reach 18-29 mg/L in sea aerosols [9], whereas today peaks of $0.96-1.30 \mathrm{mg} / \mathrm{L}$ are recorded [38]. Frequent wind storms lead to a phenomenon of accumulation of deposits which can reach 1.5-2.0 mg/L on the needles of Mediterranean pines [38], corresponding to the injury threshold in the present experiment. This suggests that European legislation on surfactants is still insufficient to protect Mediterranean pinewoods from the hazards presented by these pollutants.

As time passed after the sprayings, an increase of visible injury was observed in all species, due to the increase of chloride content in the needles and of stomatal damage. This is evidence that the surfactant deposited on the needles continues to act even after exposure. Such a "delayed-action" effect may be due to the progressive melting of deposits by air humidity and/ or to a cascade of metabolic perturbances determined by the alterations at stomatal level and the increased chloride content in the tissues.

The most sensitive species to the surfactant was confirmed to be $P$. pinea $[19,22]$. In $P$. pinea chloride ion content increased even when the plants were sprayed with sea water alone, which explains why this species is adversely affected by sea winds [18].

Although the needle chloride accumulation $\left(=\mathrm{Cl}^{-} \mathrm{PSW} 500^{-}\right.$ $\mathrm{Cl}^{-}$SW) reflected the species-specific sensitivity scale $(0.71$, $0.51,0.44 \%$ at the end of the sprayings and $2.23,1.48,1.36 \%$ two months later, in $P$. pinea, $P$. halepensis and $P$. pinaster, respectively), the difference between the last two species were small. Chloride toxicity varies from species to species [48], so that the same accumulation could induce more severe damages in a species ( $P$. halepensis) rather than in another ( $P$. pinaster). This scale of sensitivity reflects the one suggested by Guidi et al. [22] after a single spray treatment with a high quantity of a non-linear surfactant, with observations based on visible injury and needle chloride content. Although field observations show that all species are sensitive to injury caused by surfactant-polluted sea aerosol [42], these findings suggest that the degree of sensitivity is species-specific. Further investigations can identify the less sensitive species, suitable to be used for ornamental or afforestation purposes in coastal zones polluted by surfactants.

Surfactant altered the needle water status, as was recorded on the basis of water content $[4,45]$ and water potential measurements [38] on pines damaged by marine aerosol in the field. Stomatal disarray and wax erosion may damage gas and water vapour diffusion, and alter the cuticle's transport properties. The not significant correlation between water potential and the amount of epicuticular waxes suggests that the effect of stomatal disarray prevailed on wax erosion in altering the water potential, even if the role of intra-cuticular waxes cannot be ruled out. In coniferous trees, the waxes that fill the epistomatal chamber account for two thirds of the resistance to water vapour diffusion [26]: it is reasonable to suppose that this resistance increases as the waxy microtubules collapse into a more amorphous and less porous matter. In Picea abies sprayed with $50 \mathrm{mg} / \mathrm{L}$ of surfactant, no change in gas exchange or water potential was measured [8], but this study did not report indications on the status of stomata. The degeneration of the protoplasm of mesophyll cells, observed in $P$. pinea sprayed with $1000 \mathrm{mg} / \mathrm{L}$ of surfactant [12], may be a further cause of loss of function in terms of water regulation.

For biomonitoring purposes, foliar chloride content was confirmed as an excellent indicator of damage caused by surfactant-polluted sea aerosol [33], while midday water potential, being aspecific, cannot be suggested for use in biomonitoring. Stomatal structural damage, used as an indicator of atmospheric pollution [50], was also proved to be sensitive to surfactants. The symptomatology of stomatal damage was not specific, as it was reminiscent of that induced by other pollutants [50] and by environmental stressors of different origins [7, 24]. Several authors have attributed the alterations of epistomatal wax structures to the direct or indirect action exerted by the components of marine aerosol (salt and surfactants), either individually [28, 52], or combined [10, 12, 20, 34, 35, 39, 43, 44]. Needles sprayed with $\mathrm{NaCl}$ displayed some wax coalescence, but the Stomatal Damage Index enabled us to ascertain that these alterations not only did not differ from those induced by de-ionized water but also increased markedly in synergy with the surfactant. The damage to stomata was initially more severe in the species that was - as a whole - less sensitive to surfactants, $P$. pinaster, which later proved to be capable of recovering, likely because it showed a greater constitutional quantity of epicuticular waxes.

Neither the amount of epicuticular waxes nor needle wettability appeared useful indicators of surfactant injury; observation of these factors suggests the possibility that the surfactant may be partly incorporated into the epicuticular layer [45], even if a fast regeneration of waxes may be also postulated. As surfactants can dissolve wax [47], it is surprising that the progressive epicuticular erosion was not more marked than it was. Incorporation of surfactants into the waxes would explain the stochastic trend of the drop contact angle. Simply to wash the needles in water may not remove all the surface deposit of surfactant if it is somehow incorporated into the epicuticular layer. More aggressive washing techniques, e.g. in hot water or chloroform, might allow us to understand whether it is a surface adsorption. As a result, leaf wettability and epicuticular wax amount cannot be suggested to investigate the effects of surfactants on cuticles.

The main conclusions of this study are:

1. The toxicity threshold for MBAS deposited on needles is $2 \mathrm{mg} / \mathrm{L}$, a level that has been found in coastal pinewoods damaged by marine aerosol [38].

2. The toxicity threshold of chloride in foliar tissues is $2 \mathrm{mg} / \mathrm{g}$ $\mathrm{dw}$ in these species; values exceed the threshold only if surfactants are higher than $30 \mathrm{mg} / \mathrm{L}$ in the sea sprays.

3. The synergic phytotoxic effect of marine aerosol together with surfactants becomes more severe as time passes, even if no further exposures occur ("delayed-action" effect).

4. Surfactants are capable of altering needle water regulation by damaging the epistomatal waxes, not by eroding the epicuticular waxes. 
5. Among the parameters investigated, needle chloride content is potentially the most suitable for biomonitoring.

6. All three species are sensitive to injury from surfactantpolluted marine aerosol, which highlights that coastal pinewoods are an ecosystem at risk for this type of pollution.

7. The possibility of discriminating between species-specific responses $(P$. pinea $>P$. halepensis $>P$. pinaster $)$ opens up opportunities to identify less sensitive species that can be used as a coastline screen protecting more sensitive species placed behind them.

\section{REFERENCES}

[1] American Public Health Association, Standard methods for the examination of water and wastewater, 18th ed., WPCF, 1992, pp. 1-18.

[2] Appleton B., Huff R.R., French S.C., Evaluating trees for saltwater spray tolerance for oceanfront sites, J. Arboric. 25 (1999) 205-210.

[3] Astorga T., Lopez D., Carazo N., Savé R., Efecto del viento marino en la vegetación urbana del nuevo litoral barcelonés, in: Actas del $2^{\circ}$ Congreso Ibérico SECH, Spain, 1993, pp. 539-545.

[4] Badot P.M., Badot M.J., Dépérissement du pin d'Alep (Pinus halepensis Mill.) sous l'effet des embruns marins pollués. Symptômes macroscopiques et mise en évidence de perturbations hydriques dans les aiguilles, Annales Scientifiques Université FrancheComté, Besançon, Biologie-Ecologie 3 (1995) 37-43.

[5] Badot P.M., Garrec J.P., Dépérissement local du pin d'Alep (Pinus halepensis Mill.) le long du littoral méditerranéen, Rev. For. Fr. 45 (1993) 1345-1401.

[6] Badot P.M., Richard B., Lucot E., Badot M.J., Garrec J.P., Water disturbances and needle surface alterations in Pinus halepensis Mill. trees exposed to polluted sea-spray, Proceedings International Symposium Ecotoxicology of Air Compartment, Rouen, France, 1995, pp. 179-189.

[7] Bermadinger-Stabentheiner E., Physical injury, re-crystallization of wax tubes and artefacts: identifying some cause of structural alteration to spruce needle wax, New Phytol. 130 (1995) 67-74.

[8] Borghetti M., Water relations of spruce seedlings sprayed with a surfactant, Ann. Sci. For. 48 (1991) 347-355.

[9] Bussotti F., Rinallo C., Grossoni P., Gellini R., Pantani F., Del Panta S., Degrado della vegetazione costiera nella tenuta di San Rossore, La provincia pisana 4 (1983) 46-52.

[10] Bussotti F., Bellani L.M., Grossoni P., Mori B., Tani C., Anatomical and ultrastructural alterations in Pinus pinea L. needles treated with simulated sea aerosol, Agric. Mediterr. Special Vol. (1995) $148-155$.

[11] Bussotti F., Grossoni P., Pantani F., The role of marine salt and surfactants in the decline of Tyrrhenian coastal vegetation in Italy, Ann. Sci. For. 52 (1995) 251-261.

[12] Bussotti F., Bottacci A., Grossoni P., Mori B., Tani C., Cytological and structural changes on Pinus pinea L. needles following the application of an anionic surfactant, Plant Cell Environ. 20 (1997) 513-520.

[13] Cape J.N., Contact angles of water droplets on needles of Scots pine (Pinus sylvestris) growing in polluted atmospheres, New Phytol. 93 (1983) 293-299.

[14] Cape J.N., Paterson I.S., Wolfenden J., Regional variation in surface properties of Norway spruce and Scots pine needles in relation to forest decline, Environ. Pollut. 58 (1989) 325-342.

[15] Dowden H.G.M., Lambert M.J., Environmental factors associated with a disorder affecting tree species on the coast of New South Wales with particular reference to Norfolk island pine (Araucaria heterophylla), Environ. Pollut. 19 (1979) 71-84.

[16] Garrec J.P., El Ayeb N., Il problema degli aerosol marini inquinati in Francia e in Tunisia, Linea Ecologica XXXIII (2001) 51-54.
[17] Garrec J.P., Sigoillot J.P., Les arbres malades de la mer, La recherche 23 (1992) 940-941.

[18] Gellini R., Conifere, Edagricole ed., Bologna, 1985.

[19] Gellini R., Pantani F., Grossoni P., Bussotti F., Barbolani E., Rinallo C., Survey of the deterioration of the coastal vegetation in the park of San Rossore in central Italy, Eur. J. For. Pathol. 13 (1983) 296-304.

[20] Gellini R., Pantani F., Grossoni P., Bussotti F., Barbolani E., Rinallo C., Further investigation on the causes of disorder of the coastal vegetation in the park of San Rossore (central Italy), Eur. J. For. Pathol. 15 (1985) 145-157

[21] Gellini R., Pantani F., Grossoni P., Bussotti F., L'influence de la pollution marine sur la végétation côtière italienne, Bull. Ecol. 18 (1987) 213-219.

[22] Guidi L., Lorenzini G., Soldatini G.F., Risposta di specie dei generi Pinus e Quercus ad aerosol marini simulati, in presenza o meno di tensioattivi, Agric. Ital. 5/6 (1986) 55-65.

[23] Guidi L., Lorenzini G., Soldatini G.F., Phytotoxicity of sea water aerosols on forest plants with special reference to the role of surfactants, Environ. Exp. Bot. 28 (1988) 85-94.

[24] Günthardt-Goerg M.S., Keller T., Matyssek R., Scheidegger C., Environmental effects on Norway spruce needle wax, Eur. J. For. Pathol. 24 (1994) 92-111.

[25] Helenius A., Simmons K., Solubilization of membranes by detergents, Biochim. Biophys. Acta 415 (1975) 29-79.

[26] Jeffree C.E., Johnson R.P.C., Jarvis P.G., Epicuticular wax in the stomatal antechamber of Sitka spruce and its effects on the diffusion of water vapour and carbon dioxide, Planta 98 (1971) 1-10.

[27] Johnson J.D., A rapid technique for estimating total surface area of pine needles, For. Sci. 30 (1984) 913-921.

[28] Krause C.R., Identification of salt spray injury to Pinus species with scanning electron microscopy, Phytopathol. 72 (1982) 382-386.

[29] Lapucci P.L., Gellini R., Paiero P., Contaminazione chimica dell'acqua di mare quale causa di moria dei pini lungo le coste tirreniche, Ann. Acc. Ital. Sci. For. 21 (1972) 323-358.

[30] Longwell J., Maniece W.D., Determination of anionic detergent in sewage effluents and river water, Analyst 80 (1955) 167-71.

[31] Madsen T., Boyd H.B., Nylén D., Rathmann Pedersen A., Petersen G.I., Simonsen F., Environmental and health assessment of substances in household detergents and cosmetic detergent products, Environmental Project, Danish Environmental Protection Agency, $615,2001,240 \mathrm{p}$

[32] Marull J., Savé R., Bayona J.M., Efectos de la contaminación química sobre la vegetación del fronte litoral de Barcelona, Retema nov-dic (1997) 25-35.

[33] Moodie G.E., Steward R.S., Bowen S.E., The impact of surfactants on Norfolk island pines along Sydney coastal beaches since 1973, Environ. Pollut. 41 (1986) 153-164.

[34] Moricca S., Paoletti E., Comparini C., The behavior of oaks in response to natural and induced exposure to the surfactant ABS, Ann. Sci. For. 50 (Suppl. 1) (1993) 61s-65s.

[35] Moricca S., Raddi P., Di Lonardo V., Response of seven Italian beech provenances to simulated ABS treatments, Phytopathol. Mediterr. 33 (1994) 83-89.

[36] Mudry I.V., Environmental anionic surfactant pollution in some areas of the Ukraine, Gigiena i Sanitariya 3 (1998) 10-12.

[37] Myers D., Surfactant Science and Technology, 2nd ed., VCH Publ., New York, 1992.

[38] Nicolotti G., Rettori A., Paoletti E., Patetta A., Gullino M.L., Inquinamento da tensioattivi ed effetti sulle pinete costiere liguri, Linea ecologica XXXIII (2001) 35-42.

[39] Noga G.J., Knoche M., Wolter M., Barthlott W., Changes in leaf micromorphology induced by surfactants application, Angew. Bot. 61 (1987) 521-528.

[40] Paoletti E., Effects of acidity and detergents on in vitro pollen germination and tube growth in forest tree species, Tree Physiol. 10 (1992) 357-366. 
[41] Paoletti E., Indagine preliminare sul deperimento delle pinete costiere di pino d'Aleppo in Puglia, Linea Ecologica XXXIII (2001) $43-50$.

[42] Paoletti E., Nicolotti G., Bussotti F., L'inquinamento da tensioattivi ed i suoi effetti sulla vegetazione, Linea Ecologica XXXIII (2001) 21-27.

[43] Raddi P., Moricca S., Gellini R., Di Lonardo V., Effects of natura and induced pollution on the leaf wax structure of three cypress species, Eur. J. For. Pathol. 22 (1992) 107-114.

[44] Raddi P., Moricca S., Paoletti E., Effects of acid rain and surfactant pollution on the foliar structure of some tree species, in: Percy K.E. Cape J.N., Jagels R., Simpson C.J. (Eds.), Air Pollutants and the Leaf Cuticle, NATO ASI Series, Vol. G 36, Springer-Verlag, Berlin, 1994, pp. 205-216.

[45] Riederer M., Badot P.M., Garrec J.P., Richard B., Schreiber L., Sümmchen P., Uhlig M., Wienhaus O., The plant cuticle as an interface between leaves and air-borne pollutants, EUROSILVA Contribution to Forest Tree Physiology, Dourdan (France), November 7 10, 1994, Ed. INRA, Paris, Les colloques 76, 1995, pp. 101-118.

[46] Schreiber L., Bach S., Kirsch T., Knoll D., Schalz K., Riederer M., A simple photometric device analysing cuticular transport physio- logy: surfactant effect on permeability of isolated cuticular membranes of Prunus laurocerasus, J. Exp. Bot. 293 (1995) 1915-1921.

[47] Tamura H., Knoche M., Hayashi Y., Bukovac M.J., Selective solubilization of tomato fruit epicuticular wax constituents by Triton X100 surfactant, J. Pest. Sci. 26 (2001) 16-20.

[48] Townsend A.M., The search for salt tolerant trees, Arboric. J. 13 (1989) 67-73.

[49] Truman R., Lambert M.J., Salinity damage to Norfolk island pines caused by surfactants. I. The nature of the problem and effect of potassium, sodium and chloride concentration on uptake by roots, Austr. J. Plant Physiol. 5 (1979) 377-385.

[50] Turunen M., Huttunen S., A review of the response of epicuticular wax of conifer needles to air pollution, J. Environ. Qual. 19 (1990) $35-45$.

[51] Vural N., Duydu Y., Kumbur H., Monitoring of anionic surfactants in Ankara stream, Rev. Int. Contam. Ambient. 13 (1997) 47-50.

[52] Wolter M., Barthlott W., Knoche M., Noga G.J., Concentration effects and regeneration of epicuticular waxes after treatment with Triton X-100 surfactant, Angew. Bot. 62 (1988) 53-62.

[53] Zoller U., Hushan M., The nonionic surfactant pollution profile of Israel Mediterranean sea coastal water, Water Sci. Technol. 43 (2001) 245-250. 